\section{Immunophenotyping, plasticity tests and nanotagging of stem cells derived \\ from adipose tissue of wild rodent agouti (Dasyprocta prymnolopha)}

\author{
[Imunofenotipagem, testes de plasticidade e marcação com nanocristais de céluas-tronco \\ derivadas de tecido adiposo em cutias]
}

https://orcid.org/0000-0001-5488-1163 D.O. Bezerra1,

https://orcid.org/0000-0002-7662-2776 M.M.A.S. Cavalcante1,

https://orcid.org/0000-0002-6456-1080 M.L.T. Feitosa2*,

https://orcid.org/0000-0002-9247-8532 N.M. Argôlo Neto1,

https://orcid.org/0000-0002-6218-6168 R. Serakides3,

http:://orcid.org/0000-0001-5374-6242

M.M.A.S. Cavalcante ${ }^{1}$, M.L.T. Feitosa ${ }^{2}{ }^{2}$, N.M. Argôlo Neto ${ }^{1}$, R. Serakides ${ }^{3}$, M.A.M. Carvalho ${ }^{1}$ https://orcid.org/0000-0001-9165-7339

\author{
${ }^{1}$ Universidade Federal do Piauí - Teresina, PI \\ ${ }^{2}$ Universidade Estadual do Maranhão - São Luís, MA \\ ${ }^{3}$ Universidade Federal de Minas Gerais - Belo Horizonte, MG
}

\begin{abstract}
There is a growing interest in the study of unspecialized mesenchymal stem cells, for there are still some discussions about their in vitro behavior. Regenerative medicine is a science undergoing improvement which develops treatments as cell therapy using somatic stem cells. In several studies, adipose tissue is presented as a source of multipotent adult cells that has several advantages over other tissue sources. This study aimed to characterize and evaluate the tagging of mesenchymal stem cells from the agoutis adipose tissue (Dasyprocta prymonolopha), with fluorescent intracytoplasmic nanocrystals. Fibroblast cells were observed, plastic adherent, with extended self-renewal, ability to form colonies, multipotency by differentiation into three lineages, population CD90 ${ }^{+}$and CD45 - expression, which issued high red fluorescence after the tagging with fluorescent nanocrystals by different paths and cryopreserved for future use. It is possible to conclude that mesenchymal stem cells from agouti adipose tissue have biological characteristics and in vitro behavior that demonstrate its potential for use in clinical tests.
\end{abstract}

Keywords: cell culture, mesenchymal, stem cells, adipose tissue, cell differentiation, fluorescent nanocrystals

\title{
RESUMO
}

Há um interesse crescente no estudo das células estaminais mesenquimais, não especializadas, pois ainda existem algumas discussões sobre seu comportamento in vitro. A medicina regenerativa é uma ciência em fase de crescimento que desenvolve tratamentos como terapia celular utilizando células estaminais somáticas. Em vários estudos, o tecido adiposo é apresentado como uma fonte de células adultas multipotentes que tem várias vantagens em relação a outras fontes de tecido. Este estudo teve como objetivo caracterizar e avaliar a marcação de células estaminais mesenquimais do tecido adiposo de cutias (Dasyprocta prymnolopha) com nanocristais intracitoplasmáticos fluorescentes. Observaram-se células fibroblásticas, aderentes ao plástico, com autorrenovação prolongada, capacidade de formar colônias, diferenciação em três linhagens, população CD90 + e expressão CD45, que emitiram alta fluorescência vermelha após a marcação com nanocristais fluorescentes por diferentes vias, $e$ criopreservadas para uso futuro. É possível concluir que as células estaminais mesenquimais do tecido adiposo de cutias têm características biológicas e comportamentos in vitro que demonstram seu potencial para uso em testes clínicos.

Palavras-chave: cultura celular, mesenquimal, células-tronco, tecido adiposo, diferenciação celular, nanocristais fluorescentes

Recebido em 27 de abril de 2018

Aceito em 28 de dezembro de 2018

* Autor para correspondência (corresponding author)

E-mail: matheusfeitosa@professor.uema.br 


\section{INTRODUCTION}

Mesenchymal stem cells (MSC) stand out for their plasticity. The MSC were able to differentiate into mesodermal and nonmesodermal tissues, attracting even more attention in studies on their proliferation and cell specialization (Bydlowski et al., 2009). The interest of scientists for mesenchymal stem cells is continuous due to its ease of obtainment, high in vitro expandability and great therapeutic potential (Yarak and Okamoto, 2010).

The main characteristics attributed to mesenchymal stem cells present in different tissues of adult organisms are: undifferentiated morphology, extended self-renewal and multipotency demonstrated by the ability to originate a number of specialized cell types (Liu et al., 2009; Via et al., 2012; Carvalho and Goldenberg, 2012). MSC still present paracrine effects and promote angiogenesis (Schweizer et al. 2015; Zomer et al., 2015), immunomodulatory activity and expression of compatibility markers that minimize the possibility of rejection of autologous transplantations (Lee et al., 2012; Machado et al., 2013; Zhao et al., 2016).

Adipose tissue is considered a source of mesenchymal stem cells that have easy access through minimally invasive procedures, abundant amount that can be collected, and high in vitro proliferation and plasticity (Baer and Geiger, 2012; Bertassoli Neto et al. 2013). Thus, the MSC of adipose tissue were an emerging alternative since the application of autologous stem cells is prioritized in cell therapy (Nae et al., 2013). These cells promoted the recovery of several tissues and organs such as urethral smooth muscle (Zhao et al., 2012), ischemia and hepatic injury (Saidi et al., 2014), the infarcted myocardium (Gautam et al., 2015) and peripheral nerve injury (Georgiou et al., 2015).

The biology of mesenchymal stem cells from adipose tissue was studied in several animal species considering their use in cell therapy, including mice (Jang et al., 2011), rat (Schuh et al., 2014), rabbit (Gong et al., 2012), dog (Reich and Papoulas., 2012) pig (Monaco et al., 2012), goat (Ren et al., 2012; Costa et al., 2017), sheep (Fadel et al., 2011), equine (Wu et al., 2014) and also in wild animals such as collared peccary
(Tayassu tajacu) (Pessoa et al., 2014, ArgôloNeto et al., 2016) studies that provide essential data to understand their therapeutic potential.

The agouti are rodents that fit the suborder Histricomorphs, which were the first rodents in South America (Lucket and Mossman et al., 2009). There is a great need to investigate new animal models, which may have anatomical and physiological proximity to humans (Zuttion et al., 2013). The objective of this study was to characterize mesenchymal stem cells derived from agoutis subcutaneous adipose tissue (Dasyprocta prymnolopha) and evaluate the cell tagging with fluorescent nanocrystals, unpublished study in this species, for their use in cell therapies and future establishment of this rodent as a new animal model in preclinical studies.

\section{MATERIAL AND METHODS}

Six adult agoutis (Dasyprocta prymnolopha) were used, from the Center for the Study and Preservation of Wild Animals (NEPAS) of the Federal University of Piauí (UFPI). To collect the adipose tissue, the animals were contained manually and taken to the Integrated Center of Morphology and Stem Cell Research (NUPCelt), where they were premedicated with $4 \mathrm{mg} / \mathrm{kg}$ of meperidine hydrochloride by IM route and anesthetized after $15 \mathrm{~min}$ with $35 \mathrm{mg} / \mathrm{kg}$ ketamine hydrochloride associated to $3 \mathrm{mg} / \mathrm{Kg}$ of midazolam maleate. SISBIO (Biodiversity Information and Authorization System) authorization - Case $n^{\circ}$. 330582. The animal care and experimental procedures were conducted following the guidelines of the Ethics Committee on Animal Experimentation, Federal University of Piauí (CEUA-UFPI, Process nº. 018/14).

The subcutaneous adipose tissue (SAT) of the cervical region was collected after the trichotomy and local antisepsis. From a $3 \mathrm{~cm}$ incision, the tissue was pulled with anatomical forceps and dissected with a blunt tip Metzembaum scissors. The samples were placed in $50 \mathrm{ml}$ conical tubes with a phosphate-buffered saline (PBS) with $10 \%$ penicillin/streptomycin and forwarded to the stem cell laboratory. After these procedures, the animals were followed in NEPAS, with the antisepsis of the incision site being done with Dakin solution and topical administration of antibiotics and steroidal anti- 
inflammatory (oxytetracycline hydrochloride and hydrocortisone, Terra-cortril ${ }^{\circledR}$, Pfizer do Brasil ${ }^{\circledR}$ ).

The obtained adipose tissue samples were washed with PBS in order to receive physical and chemical dissociation processes with the use of scalpel blades into a Petri dish containing $5 \mathrm{ml}$ of type I collagenase for 5 minutes. After dissociation, the adipose tissue from each animal was transferred to a conical $15 \mathrm{ml}$ tube properly identified with the addition of $5 \mathrm{ml}$ of culture medium consisting of $84 \%$ of DMEM, $15 \%$ of bovine fetal serum and $1 \%$ of penicillin/streptomycin. The tubes remained in a water bath at a temperature of $37^{\circ} \mathrm{C}$ for 15 minutes and were agitated in the vortex every 3 minutes. They were then centrifuged at $1500 \mathrm{rpm}$ for 10 minutes at $20^{\circ} \mathrm{C}$ and the solution transferred to a $100 \mu \mathrm{m}$ mesh filter connected to a conical $15 \mathrm{ml}$ tube. The fragments retained on the filter were aspirated with a pipette and seeded in $25 \mathrm{~cm}^{2}$ culture bottles containing culture medium, while the filtered content was centrifuged at $1500 \mathrm{rpm}$ for 10 minutes at $20^{\circ} \mathrm{C}$ to obtain the cell pellet, which was then seeded in to $25 \mathrm{~cm}^{2}$ culture bottles. The bottles were kept in an incubator containing $\mathrm{CO} 2-95 \%$ at $37^{\circ} \mathrm{C}$ for isolation of the adipose-derived mesenchymal stem cells (AdMSCs).

The primary cell culture was observed daily for the follow up of the cell proliferation and verification of possible sources of contamination, with the culture medium changed every three days. The images of the cells in culture were viewed in $4 \mathrm{x}, 10 \mathrm{x}, 20 \mathrm{x}$ and 40x objective in inverted light microscope (COLEMAN NIB$100)$ and stored by image capture system (Studio Launcher).

The primary culture was trypsinized when cell expansion reached $80 \%$ confluence. Initially, the culture medium was aspirated and the bottle washed with PBS, adding $1.5 \mathrm{ml}$ of trypsin for 5 minutes. After this period, $3 \mathrm{ml}$ of culture medium was added to neutralize the action of trypsin and the cell solution was centrifuged for 10 minutes to obtain the pellet. After trypsinization, the cells in the first passage (P1) were seeded into 2 bottles of $25 \mathrm{~cm}^{2}$ and properly identified at each observation of $80 \%$ confluence. The culture was gradually expanded until the fifth passage when characterization and in vitro behavior studies were conducted.
For the CFU-F assay, $1 \times 10^{3}$ cells were seeded in $60 \times 15 \mathrm{~cm}$ cultivation plates in triplicate. The culture was observed daily in order to verify the colony-forming for 14 days. After this period, the cells were fixed with $4 \%$ paraformaldehyde for 30 minutes and stained with Giemsa for 10 minutes at room temperature, washing the excess with distilled water. The colonies were counted on the surface of the culture plate under an inverted light microscope, and the average number of colonies present on the plates was calculated.

The evaluation of AdMSC kinetics was performed by seeding $1 \times 10^{5}$ cells $/ \mathrm{ml}$ in 20 culture bottles of $25 \mathrm{~cm}^{2}$, and the number of cells that proliferated in a bottle was counted every 24 hours. The culture bottle's media were changed every three days to maintain the availability of nutrients of the culture and values for the number of cells were tabulated for growth curve assessment.

Cell counting, which determines the samples' viability and concentration, was performed using the Trypan blue exclusion method. After addition and homogenization of $50 \mu \mathrm{L}$ of cell suspension in $50 \mu \mathrm{L}$ of Blue Trypan solution $(50 \mu \mathrm{L}$ of $4.25 \%$ sodium chloride in $200 \mu \mathrm{L}$ of Trypan Blue) a $10 \mu \mathrm{L}$ aliquot in a Neubauer chamber was observed in optical microscope (10x objective). The cell concentration and viability were determined by cell counting in 4 diagonal fields, with the total cells multiplied by 2 (dye dilution) and by $10^{4}$ (camera depth and correction per $\mathrm{ml}$ ) and then dividing this value figure by the number of quarters counted in the Neubauer chamber, as shown below.

Induction of adipogenic differentiation was performed on a 6-well plate seeded at initial concentration of $2 \times 10^{4}$ cells/well. The cells were initially kept in growth medium for three days until they reached $70 \%$ confluence. The culture medium was replaced by an adipogenic differentiation medium (STEMPRO $^{\circledR}$ Adipogenesis Differentiation Kit) and changed every $72 \mathrm{~h}$ for 14 days. Cells were fixed with $4 \%$ paraformaldehyde for 30 minutes at room temperature and washed with distilled water for Oil Red staining. Then, they were covered with $60 \%$ isopropyl alcohol for 5 minutes and stained with Oil Red for 5 minutes. The dye was removed and the plate washed with $60 \%$ 
isopropyl alcohol followed by washings with distilled water until there was no more visible precipitate.

The osteogenic differentiation was performed on a 6-well plate, with initial concentration of $2 \times 10^{4}$ cells/well in growth medium for three days to allow cell adherence. Then the culture medium was replaced by STEMPRO ${ }^{\circledR}$ Osteogenesis Differentiation Kit, and changed every 72 hours for 14 days. Cells were fixed with $4 \%$ paraformaldehyde for 30 minutes at room temperature and washed with distilled water to Alizarin Red staining for 5 minutes, the dye being removed and several washings with distilled water performed.

For chondrogenic differentiation induction, the initial concentration of $2 \times 10^{4}$ cells/well was seeded on a 6-well plate with culture medium for three days. After three days, a 70\% confluent in the culture was observed. That is when the medium was replaced by STEMPRO ${ }^{\circledR}$ Condrogenesis Differentiation Kit, being changed every 72 hours for 14 days. Cells were fixed with $4 \%$ paraformaldehyde for 30 minutes at room temperature and washed with distilled water to Alizarin Red staining for 5 minutes, the dye being removed and several washings with distilled water performed.

Immunophenotypic characterization of AdMSC was conducted by flow cytometry by CD45 (Rabbit polyclonal Anti-CD45 Antibody - FITC, abcam) and CD90 (Rabbit Polyclonal Anti-Thy1 Antibody, Alexa Fluor Conjugated, Bioss) cell surface molecule expression analysis, using a
FACS CANTO II and Cell Quest (FACS DIVA) software, yielding 20,000 events per tested sample. The concentration of $2.5 \times 10^{5}$ cells in the fourth passage (P4) were incubated with conjugated FITC antibodies for 30 minutes, and after two washes with PBS, they were analyzed using blue laser $(488 \mathrm{~nm})$, performing the selffluorescence negative control.

AdMSCs were tagged with fluorescent nanocrystals (Q-Tracker 655). The marker's components were homogenized $(2 \mathrm{ml}$ of component $\mathrm{A}$ and $2 \mathrm{ml}$ of component B) and added to the cell suspension in P5 kept in a $\mathrm{CO}_{2}$ incubator for 45 minutes, being agitated every 15 minutes. The content was resuspended in $1 \mathrm{ml}$ of culture medium and centrifuged at $1500 \mathrm{rpm}$ for 10 minutes. The pellet was resuspended in culture medium, a drop of the solution with cells was placed on a slide and covered with a coverslip for immediate checking of the tagging efficiency. The content of cells tagged with nanocrystals was seeded in wells containing coverslips in four different passages, being analyzed with a fluorescence microscope to evaluate the maintenance of the fluorescence in daughter cells.

\section{RESULTS}

MSCs isolation and expansion can be obtained by explant or cell pellet of dissociated adipose tissue. AdMSC isolation started with the release of adherent fibroblastoid cells that kept its high proliferative activity and reached $80 \%$ confluence in 10 days (Figure 1).

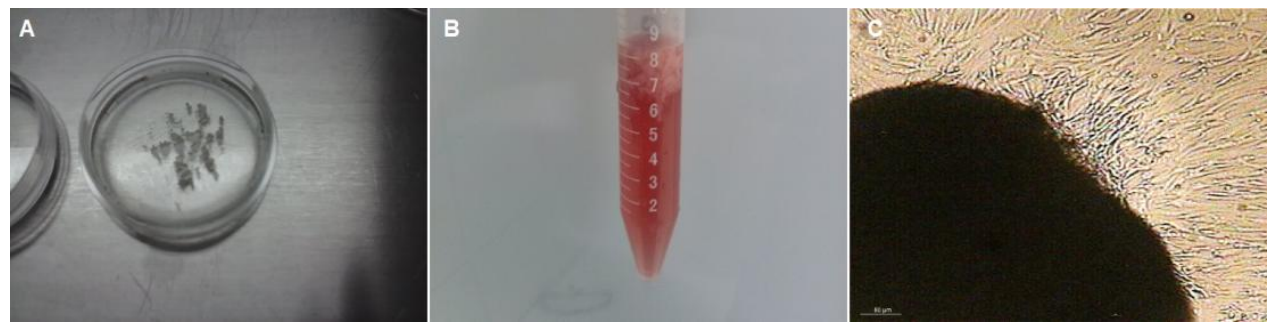

Figure 1. Agoutis' AdMSC isolation (Dasyprocta p.). A - Fragments of adipose tissue dissociated cell components. B - Cell pellets dissociated from the adipose tissue. C - Subcutaneous adipose tissue explant releasing a large amount of AdMSC

Colony-forming in primary culture is restricted to the edges of the fragments in cultures initiated with explant with a large amount of cells being released from the tissue, which grew close to or overlapping the adjacent cells. In the culture resulting from the pellet of cells dissociated from the adipose tissue, the colonies were distributed in the culture area forming a monolayer culture. 
In the CFU-F assay, from the initial density of $1 \times 10^{3}$, an average of 5 colonies were formed, representing $0.5 \%$ of $\mathrm{CFU}$ obtained from the seeded cell concentration.

Three stages were identified in the growth curve: the lag phase observed during the first four days; the log phase between the fifth and the eighth day, and the plateau phase from the ninth to the twentieth day, with cell concentrations ranging from $1.1 \times 10^{6}$ and $2.1 \times 10^{6}$ cells $/ \mathrm{ml}$. The values for cell concentrations are shown in the chart (Figure 2).
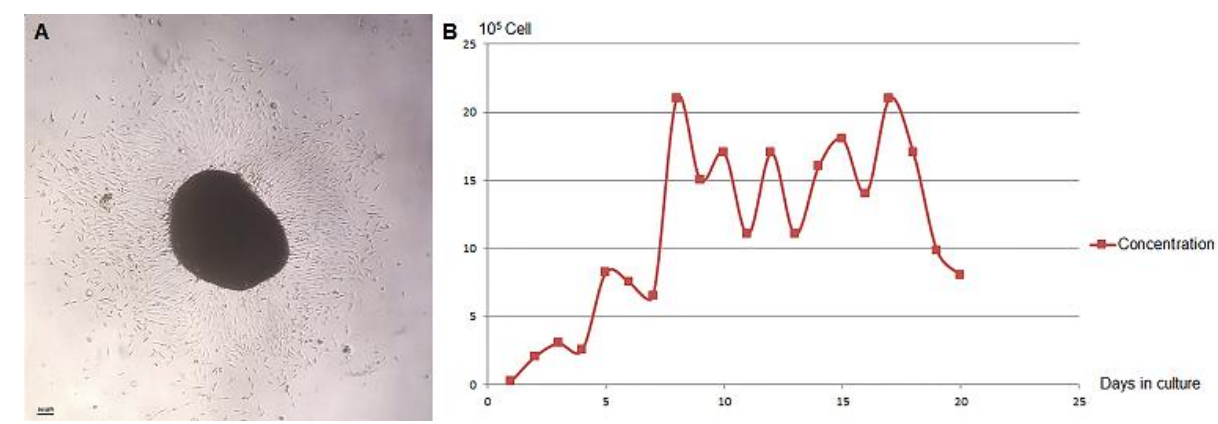

Figure 2. Agouti's AdMSC colony-forming and growth curve (Dasyprocta p.). A - Colony formed by AdMSC. B - AdMSC growth curve relating the culture days and cell concentration.

Changes in culture were observed in differentiation assays, except in the negative control in which the presence of fibroblastoid cells prevailed. Cells subjected to differentiation for 14 days showed evident characteristics of specialization, while the ones subjected to the assays for 21 days showed a reduction of these characteristics and signs of apoptosis in many cells in the culture. In adipogenic differentiation, AdMSCs formed several intracytoplasmic lipid vesicles and acquired multilocular adipocytes morphology. Lipid vesicles were stained with Oil Red (Figure 3A, B, C). In osteogenic differentiation, the formation of calcium deposits and the presence of cells of osteoblastic lineage with cuboid and polyhedral morphology were observed, however, they were not stained with Alizarin Red (Figure 3D, E, F). In chondrogenic differentiation, the formation of a thin cell membrane with a whitish edge, with subsequent monolayer organization zones was observed: chondroprogenitor cells condensate, which is a group of rounded cells with polygonal to oval shape, ranging in size, in a region rich in extracellular matrix; transition line and matrix accumulation zone intensively stained with Alcian Blue.

It is interesting to note that the tissue arrangement formed, with the presence of isogenic groups, is quite characteristic of hyaline cartilages (Figure 3G, H, I).

The nanocrystal fluorescent tagging was observed over 5 passages in culture; the cells emitted high red fluorescence seen as bright spots, and during the passages there was a progressive decrease in the number of fluorescent spots (Figure 5). 


\section{Rocha et al.}

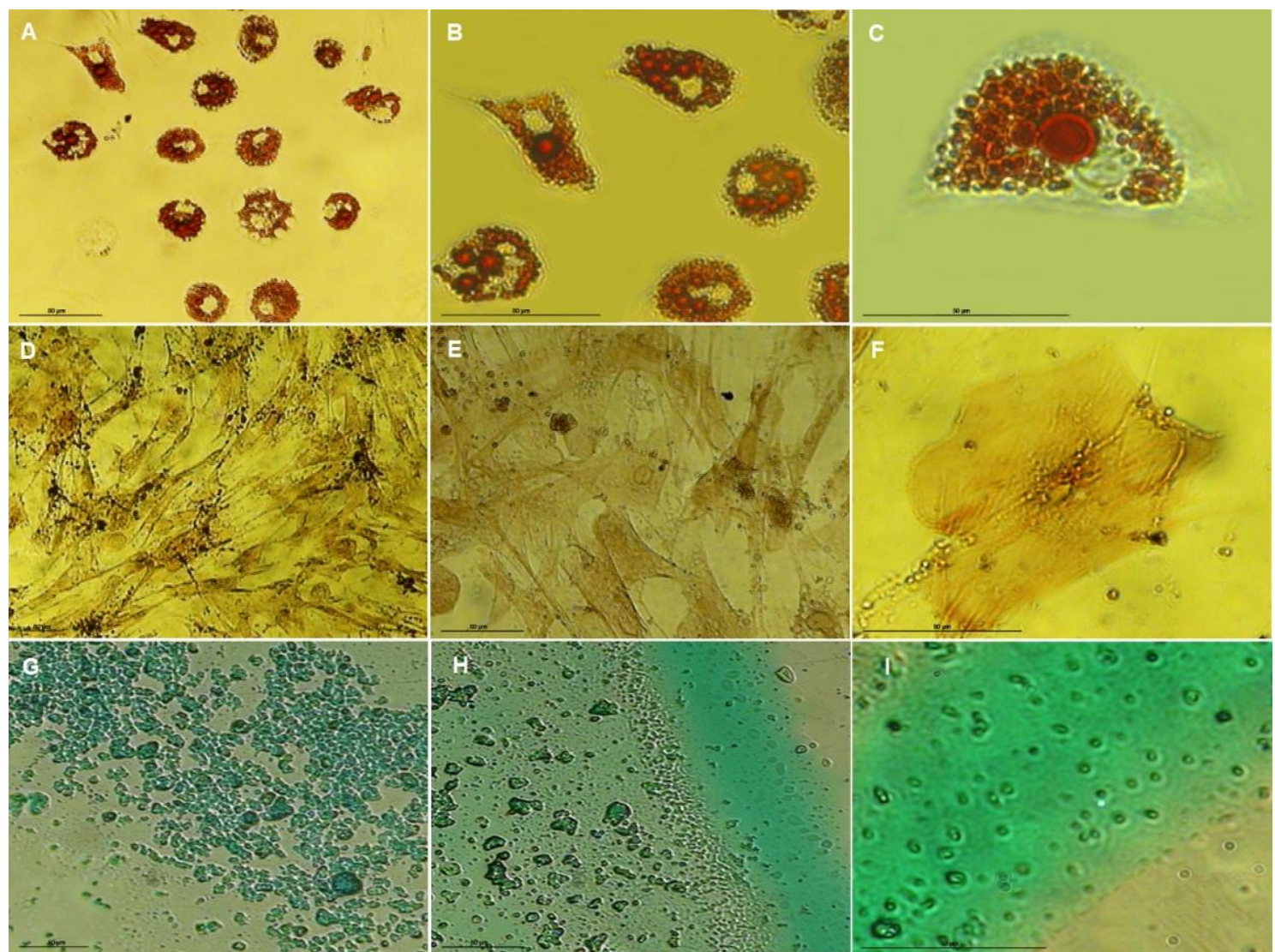

Figure 3. Differentiation assays with agouti's AdMSC (Dasyprocta p.). A, B, C - AdMSC adipogenic differentiation with formation of lipid vesicles stained with Oil Red; 10x, 20x and 40x objective. D, E, F AdMSC osteogenic differentiation with cells of osteoblastic lineage and calcium deposits stained with Alizarin Red; 4x, 10x and 40x objective. G, H, I - AdMSC chondrogenic differentiation with the presence of cells in different stages of differentiation and rich extracellular matrix intensively stained with Alcian Blue; 10x and 40x objective. In AdMSC population immunophenotyping, $85 \%$ of the cells did not express CD45, 86.6\% did not express CD105 and 79\% of the cells expressed CD90. The expression of membrane surface molecules is shown in Figure 4.
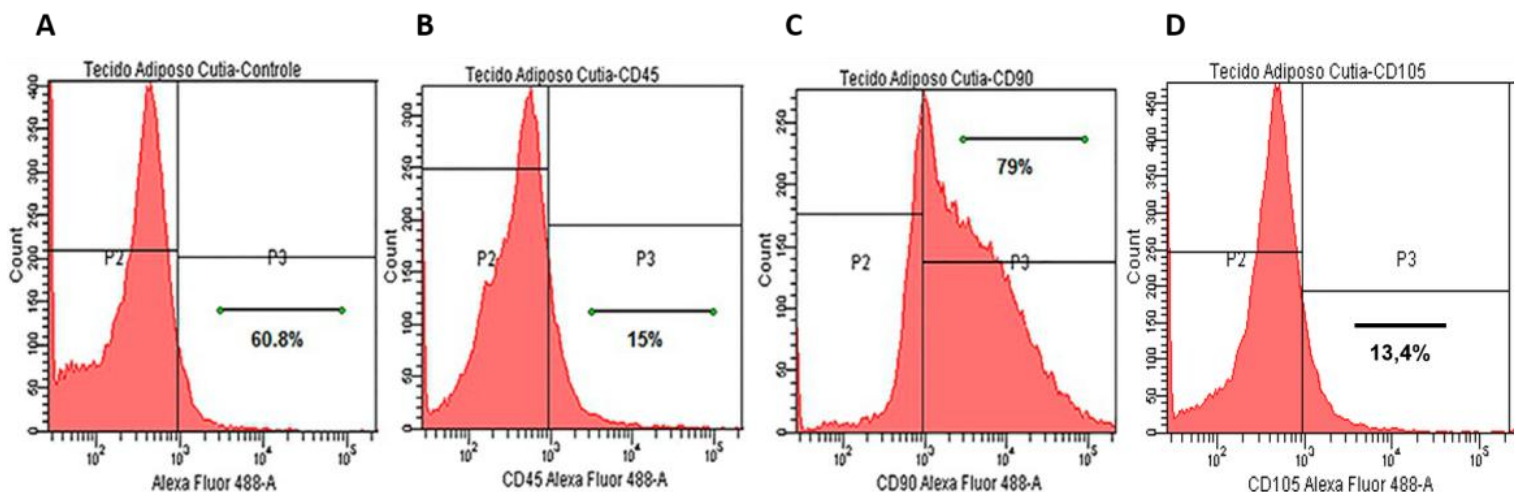

Figure 4. Immunophenotypic characterization of agouti's AdMSC (Dasyprocta p.) by flow cytometry. A Negative control. B - CD45 expression. C - CD90 expression. D - CD105 negative expression. 

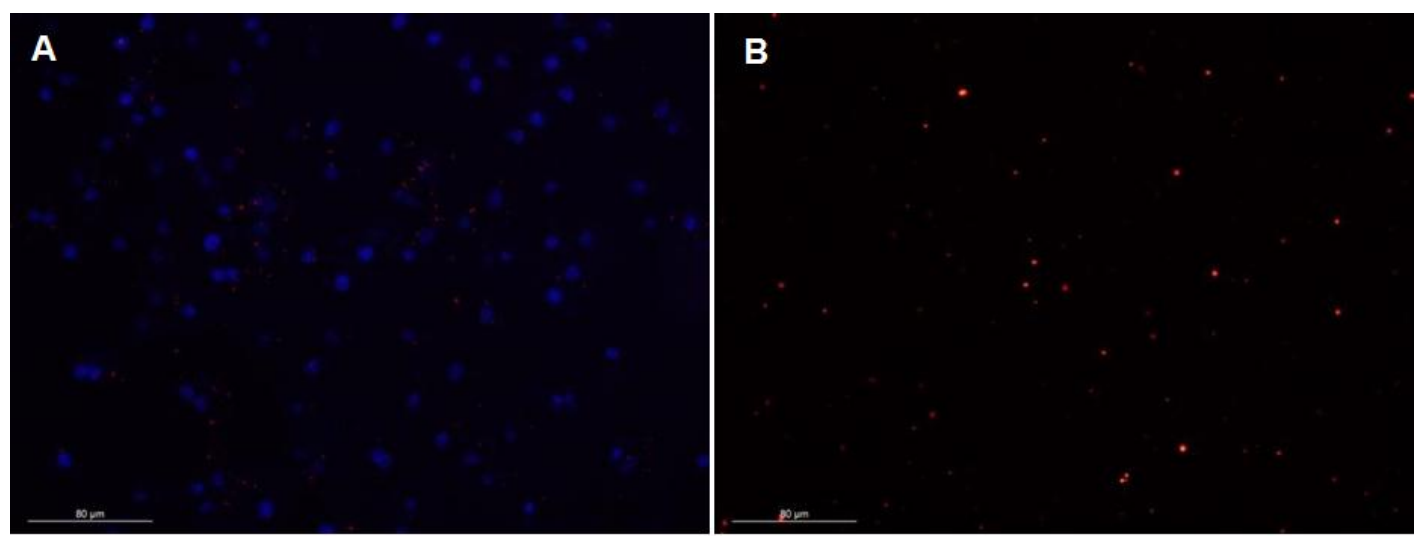

Figure 5 Agouti's AdMSC (Dasyprocta p.) tagged with fluorescent nanocrystals. A- Agouti's AdMSC tagged with nanocrystals and DAPI. B - AdMSC immediately after tagging, presenting a great number of nanocrystals.

\section{DISCUSSION}

The number and size of agouti's AdMSC colonies may vary, since it depends on the amount of cells obtained from the tissue sample used in the primary culture. The number of isolated AdMSCs is also influenced by the amount of fibrous tissue and blood in the tissue fragment (Patricio et al., 2013). In this study, a small number of colonies was observed in the CFU-F assay performed with secondary culture, demonstrating that the initial density of $1 \times 10^{3}$ is not enough to obtain colonies. The discrete colony formation when a low density of cells is seeded in the culture can be changed with the increase of initial cell density, once it is the main factor influencing the formation of distinct colonies (Zhang and Chan, 2010). Data on the fibroblastoid colony-forming capacity and the multipotentiality of human adipose tissue derived stem cells were important for its distinction from fibroblast cells (Alt et al., 2011). In addition, the CFU-F assay is an important method for the establishment of cultures by the verification of in vitro self-renewal, relating to cell density and the culture area.

Analyzing the agouti's AdMSC growth curve, it is observed that these cells are able to perform a large number of cell divisions, especially by maintaining high concentrations. The capacity for extended self-renewal also occurs in AdMSC. It was possible to verify high proliferation at 25 days growth curves with slight growth inhibition by contact between cells. This quick cell expansion with the maintenance of phenotype and pluripotency indicates that adipose tissue is a better source of mesenchymal stem cells than bone marrow (Zhu et al., 2008) Small growth curve ranges can bring information about the cell proliferation from mice's AdMSC proliferation at intervals of 48 hours and 72 hours. The proliferative index is greater when using collagenase than when it is associated to trypsinEDTA (Ginani et al., 2013) as was observed in this study. In agoutis, the lag phase showed a slight increase in the cell concentration; the log phase showed exponential growth; and in the plateau phase, where a progressive decrease of the cellular concentration was expected, it was observed that the proliferation maintained a pattern of one day of growth interpolated by a day of cell concentration decrease, considerably reducing only in the last two days.

Agoutis' AdMSC have plasticity for adipogenic, osteogenic and chondrogenic differentiation, confirming the multipotentiality of these cells. The adipogenic differentiation shows that multilocular adipocytes tend to become more mature and specialized just like subcutaneous adipose and visceral tissue of humans and mice, being the subcutaneous tissue more specialized in mature adipocytes (Gong et al., 2012) The level of adipogenic and osteogenic specialization after 21 days of induction was higher in cells from adipose tissue than in MSCs of the bone marrow and human skin, whereas the preferred differentiation lineage of MSC of different compartments may be an influencing factor during the induction of differentiation (AlNbaheen et al., 2013. 
In agoutis' AdMSC osteogenic differentiation, osteoblastic lineage cells were observed, which synthesized calcium deposits in the extracellular matrix. However, the osteogenic specialization can vary in AdMSC from different anatomical origins or different passages (Requicha et al., 2012). The change of AdMSC fibroblastoid of mice for osteoblasts and the formation of mineralization nodules was also sufficient to prove this lineage specialization (Carvalho et al., 2013). In the process of differentiation, extracellular calcium can modulate the osteogenic and chondrogenic specialization. This approach is interesting for osteochondral tissue engineering (Mellor et al., 2015).

In this experiment a highly specialized AdMSC chondrogenic differentiation in monolayer was possible, which is unusual for this method. In experiments in Tayassuidae, collared peccary (Tayassu tajacu), the chondrogenic differentiation by this method is limited by a nodule resulting from induction (Pessoa et al., 2014). Most experiments use the micromass culture method for chondrogenic specialization due to the need of a three-dimensional environment (Patrício et al., 2013; Bravo et al., 2012).

The differentiation zones in this study may be related to the in vivo chondroprogenitor cell development and it is possible that agoutis' AdMSC have a greater tendency to group cells and, therefore, a greater potential for chondrogenic lineage. In the organisms, the formation of cartilage begins when a mass of mesenchymal cells is stimulated to proliferate, differentiate and move around secreting cartilage matrix molecules that becomes more abundant with the chondrocytes specialization (Carvalho and Collares-Buzzato., 2005; Telser et al., 2008). The presence of rounded cells similar to chondrocytes, surrounded by a large amount of extracellular matrix, can be observed in histological sections in literature (Ovalle and Nahirney, 2008). A similar result was reproduced in this assay: a chondroprogenitor cell condensate, which is a group of rounded cells with polygonal to oval shape, ranging in size, producing cartilage matrix. These cells apparently become more differentiated towards the edge and form a transition line followed by a matrix accumulation zone composed of proteoglycans, randomly separating small chondrocytes without any intercellular junctions. These results represent a wide potential of agoutis' AdMSC for differentiation in the chondrogenic lineage.

In differentiation assays in trilineage for 21 days, the reduction of AdMSC specialized morphological characteristics and apoptosis showed the depletion of cells in relation to inducing substances and to the inappropriate microenvironment for tissue formation. This may occur by extensive induction period on high kinetics cells and by greater specialization where greater physical, chemical and biological requirements are provided. Experimenting on dogs, multipotent cells in the adipose tissue differentiated after 21 days, however, cell deaths and disposal of cultures subjected to differentiation in the three lineages were reported (Patricio et al., 2013).

The low expression of CD45 and high expression of CD90 show that the agoutis' AdMSC population is distinct from the hematopoietic lineage and express population marker of mesenchymal stem cells. In other experiments the expression of CD90 with a value above $80 \%$ in AdMSC populations of different species was verified (Al-Nbaheen et al., 2013; Carvalho et al., 2013; Maia et al., 2012). However, as MSC markers from bone marrow and adipose tissue in humans, they are the same in dermis fibroblast cells and olfactory epithelium, and the development of a standardized technique for the isolation of different populations in clinical practice (Wetzig et al., 2013) is required. In humans, MSCs from bone marrow, adipose tissue, umbilical cord and neural origin showed common expression for a set of markers, the difficulty to standardize the reported immunophenotypic profile in other studies being attributed to the absence of evaluation of the set of specific marker variations in the protocols used and the lack of characterization of several obtaining sites (New et al., 2015)

Despite the minimum criteria proposed for human MSCs (Dominici et al., 2006), CD markers are quite controversial. For example, CD34 is defined as a negative marker, perhaps, advential pericyte cells have been shown to have multipotential capacity but are CD34+ (Campagnolo et al., 2010). Other markers such as CD105 are on most Mesenchymal cells 
including fibroblasts (Mandolim et al., 2010) In this study, CD 105 presents low expression, despite the CD 90 high expression. In addition, it should be considered that there are no specific markers for the species in question (Dasyprocta prymnolopha).

AdMSC tagging with nanocrystals was observed by five passages, demonstrating that they were incorporated into the cell cytoplasm and transferred to subsequent cellular generations. This tagging was effective for the tracking of transplanted cells in cell therapy (Yukawa et al., 2009) These findings allow us to infer that the nanotagging is used effectively and can be feasible for cell tracking.

\section{CONCLUSION}

It is concluded that the mesenchymal stem cells derived from adipose tissue of wild rodent agouti show high proliferative activity, wide potential for multilineage differentiation, originating adipocytes, osteoblast lineage cells and specialized chondroprogenitors. The high expression of CD90 and low CD45 expression show that these cells are a distinct population of hematopoietic lineage and express mesenchymal stem cells markers. The fluorescent tagging with intracytoplasmic nanocrystals was efficient for the cell's tracking through different cell generations. Our data strongly suggest that stem cells isolated from adipose tissue of wild rodent agouti represent a valuable tool for biomedical research as a promising alternative for use in cell therapy assays.

\section{ACKNOWLEDGMENTS}

We are thankfull to the National Scientific and Technological Development Council - CNPq (Process: 552400/2011-4) for their financial support.

\section{REFERENCES}

AL-NBAHEEN, M.; VISHNUBALAJI, R.; ALI, D. et al. Human stromal (Mesenchymal) stem cells from bone marrow, adipose tissue and skin exhibit differences in molecular phenotype and differentiation potential. Stem Cell Rev. Rep., v.9, p.32-43. 2013.
ALT, E.; YAN, Y.; GEHMERT, S. et al. Fibroblasts share mesenchymal phenotypes with stem cells, but lack their differentiation and colony-forming potential. Biology of the cell / under the auspices of the European Cell Biology Organization. Biol. Cell, v.103, p.197-208, 2011.

ARGÔLO NETO, N.M.; FEITOSA, M.L.T.; SOUSA, S.S. et al. Isolation, expansion, differentiation and growth kinetics essay in mesenchymal stem cells culture from the bone marrow of collared peccaries (Tayassu tajacu). Acta Sci. Vet., v.44, p.1-11, 2016.

BAER, P.C.; GEIGER, H. Adipose-derived mesenchymal stromal / stem cells: tissue localization, characterization, and heterogeneity. Stem Cells Int., v.2, p.1-11, 2012.

BERTASSOLI, B.M.; NETO, A.C.A.; OLIVEIRA, F.D. et al. Mesenchymal stem cells - emphasis in adipose tissue. Braz. Arch. Bio. Technol., v.56, p.607-617, 2013.

BRAVO, M.O.; MORAES, J.M.; DUMMONT, C.B.S. et al. Isolamento, expansão e caracterização de células-tronco do tecido adiposo de equinos. Ars Vet., v.28, p.66-74, 2012.

BYDLOWSKI, S.P.; DEBES, A.A.; MASELLI, L.M.F.; JANZ, F.L. Características biológicas das células-tronco mesenquimais. Braz. J. Hematol. Hemot., v.31, p.25-35, 2009.

CARVALHO, A.C.C.; GOLDENBERG, R.C.S. Células-tronco mesenquimais: conceitos, métodos de aplicação e obtenção. São Paulo: Publisher Atheneu, 2012. 208p.

CARVALHO, P.H.; DAIBERT, A.P.; MONTEIRO, B.S. et al. Differentiation of adipose tissue-derived mesenchymal stem cells into cardiomyocytes. Braz. Arch. Card., v.100, p.82-9, 2013.

CAMPAGNOLO, P.; CESSELli, D.; AL HAJ ZEN, A. et al. Human adult vena saphena contains perivascular progenitor cells endowed with clonogenic and proangiogenic potential. Circulation, v.121, p.1735-1745, 2010.

CARVALHO, H.F.; COLLARES-BUZZATO, C.B. Células - uma abordagem multidisciplinar. São Paulo: Manole, 2005. 452p. 
COSTA, C.R.M.; FEITOSA, M.L.T.; BEZERRA, D.O. et al. Labeling of adiposederived stem cells with quantum dots provides stable and long-term fluorescent signal for ex vivo cell tracking. In Vitro Cell Dev. Biol. Anim., v.53, p.363-370, 2017.

DOMINICI, M.; LE BLANK, K.; MUELLER, I. et al. Minimal criteria for defining multipotent mesenchymal stromal cells. Cytotherapy, v.8, p.315-317, 2006.

FADEL, L.; VIANA, B.R.; FEITOSA. M.L. et al. Protocols for obtainment and isolation of two mesenchymal stem cell sources in sheep. Acta Cir. Bras., v.26, p.267-273, 2011.

GAUTAM, M.; FUJITA, D.; KIMURA, K. et al. Transplantation of adipose tissue-derived stem cells improves cardiac contractile function and electrical stability in a rat myocardial infarction model. J. Mol. Cell Cardiol., v.81, p.139-149, 2015.

GEORGIOU, M.; GOLDING, J.P.; LOUGHLIN, A.J.; KINGHAM, P.J.; PHILLIPS, J.B. Engineered neural tissue with aligned, differentiated adipose derived stem cells promotes peripheral nerve regeneration across a critical sized defect in rat sciatic nerve. Biomaterials, v.37, p.242-251. 2015.

GINANI, F.; SOARES, D.M.; BARBOZA, C.A. Rendimento de Células mesenquimais do tecido adiposo submetidas a diferentes protocolos de extração. Braz. J. Health Sci., v.17, p.65-70, 2013.

GONG, L.; WANG, C.; LI, Y. et al. Effects of human adipose-derived stem cells on the viability of rabbit random pattern flaps. Cytotherapy, v.16, p.496-507, 2012.

JANG, H.J.; CHO, K.S.; PARK, H.Y.; ROH, H.J. Adipose tissue-derived stem cells for therapy of airway allergic diseases in mouse. Acta Histochem., v.113, p.501-507, 2011.

LEE, J.M.; JIEUN, J.; LEE, H.J.; KIM, G.J. Comparison of immunomodulatory effects of placenta mesenchymal stem cells with bone marrow and adipose mesenchymal stem cells. Int. Immunopharmacol., v.13, p.219-224, 2012.

LIU, Z.J.; ZHUGE, Y.; VELAZQUEZ, O.C. Trafficking and differentiation of mesenchymal stem cells. J. Cell Biochem., v.106, p.984-991, 2009.
LUCKETT, W.P.; MOSSMAN, H.W. Development and phylogenetic significance of the fetal membranes and placenta of the African hystricognathous rodent Bathyergus and Hystrix. Am.. J Anat., v.162, p.265-285, 2009.

MACHADO, C.V.; TELLES, P.D.S.; NASCIMENTO, I.L.O. Immunological characteristics of mesenchymal stem cells. $J$. Hematol., v.35, p.62-67, 2013.

MAIA, L.; LANDIM-ALVARENGA， F.C.; GOLIM, M.A. et al. Potencial de transdiferenciação neural das células-tronco mesenquimais da medula óssea de equino. Pesqui. Vet. Bras., v.32, p.444-452, 2012.

MELLOR, L.F.; MOHITI-ASLI, M.; WILLIAMS, J. et al. Extracellular calcium modulates chondrogenic and osteogenic differentiation of human adipose-derived stem Cells: a novel approach for osteochondral tissue engineering using a single stem Cell source. Tissue Eng. Part A, v.21, p.2323-2333, 2015.

MONACO, E.; BIONAZ, M.; RODRIGUEZZAS, S.; HURLEY, W.L.; WHEELER, M.B. Transcriptomics comparison between porcine adipose and bone marrow mesenchymal stem Cells In Vitro during osteogenic and adipogenic differentiation. Plos One, v.7, p.e32481, 2012.

NAE, S.; BORDEIANU, I.; STĂNCIOIU, A.T.; ANTOHI, N. Human adipose-derived stem cells: definition, isolation, tissue engineering applications. Rom. J. Morphol. Embryol., v.54, p919-924, 2013.

NEW， S.E.P.; ALVAREZ-GONZALEZ， C.; VAGASKA, B. et al. A matter of identity phenotype and differentiation potential of human somatic stem cells. Stem Cell Res., v.15, p.1-13, 2015.

OVALLE, W.; NAHIRNEY, P.C. Bases da histologia. Rio de Janeiro: Elsevier, 2008. 536p.

PATRICIO, L.F.L.; REBELATTO, C.L.K.; BROFMAN, P.R.S. et al. Isolamento e caracterização de células mesenquimais do tecido adiposo de cães. Arq. Bras. Med. Vet. Zootec., v.65, p.946-954, 2013.

PESSOA, G.T.; FEITOSA, M.L.T.; ARGOLONETO, N.M. et al. Isolation, culture and differentiation potential of collared peccary (Tayassu tajacu) adipose-derived stem Cells. Acta Sci. Vet., v.42, p.1233, 2014. 
REICH, J.; PAPOULAS, O. Caprin controls follicle stem cell fate in the Drosophila ovary. Plos One, v.7, p.e35365, 2012.

REN, Y.; WU, H.; ZHOU, X. et al._Isolation, expansion, and differentiation of adipose-derived stem cells goat. Res. Vet. Sci., v.93, p.404-411, 2012 .

REQUICHA, J.F.; VIEGAS, C.A.; ALBUQUERQUE, C.M. et al. Effects of anatomical and cell passage number on the stemness and osteogenic differentiation potential of canine adipose-derived stem cells. Stem Cell Rev. Rep., v.8 p.1211-222, 2012.

SAIDI, R.F.; RAJESHKUMAR, B.; SHARIFTABRIZI, A. et al. Human adipose derived mesenchymal stem Cells attenuate liver ischemia-reperfusion injury and promote liver regeneration. Surgery, v.156, p.1225-1231, 2014.

SCHUH, C.M.; HEHER, P.; WEIHS, A.M. et al. In vitro extracorporeal shock wave treatment enhances stemness and preserves multipotency of rat and human adipose-derived stem cells. Cytotherapy, v.16, p.1666-1678, 2014.

SCHWEIZER, R.; TSUJI, W.; GORANTLA, V.S. et al. The role of adipose-derived stem Cells in breast cancer progression and metastasis. Stem Cells Int., v.2015, p.1-17, 2015.

TELSER, A.G.; YOUNG, J.K.; BALDWIN, K.M. Histologia. Rio de Janeiro: Elsevier; 2008. 464p.

VIA, A.G.; FRIZZIERO, A.; OLLIVA, F. Biological properties of mesenchymal stem Cells from different sources. Muscle Ligaments Tendons J., v.2, p.154-162, 2012.

WETZIG, A.; ALAIYA, A.; AL-ALWAN, M. et al. Differential marker expression by cultures rich in mesenchymal stem cells. BMC Cell Biol, v.14, p.54, 2013.
WU, H.; HAN, D.; JIANG, Z. et al. Equine adipose-derived stem cell (ASC) expressions BAFF and its receptors, which may be associated with the differentiation process of ASC towards adipocyte. Int. Immunopharmacol., v.18, p.365372, 2014.

YARAK, S.; OKAMOTO, O.K. Células-tronco derivadas de tecido adiposo humano: desafios atuais e perspectivas clínicas. Braz. Ann. Dermatol., v.85, p.647-656, 2010.

YUKAWA, H.; MIZUFUNE, S.; MAMORI, C. et al. Quantum dots for labeling adipose tissuederived stem Cells. Cell Transplant, v.18, p.591599, 2009.

ZHANG, L.; CHAN, C. Isolation and enrichment of rat mesenchymal stem cells (MSCs) and separation of single-colony derived MSCs. J. Vis. Еxp., v.37, p.2-5, 2010.

ZHAO, Q.; REN, H.; HAN, Z. Mesenchymall stem cells: Immunomodulatory capability and clinical potential in immune diseases. J. Cell Immunother., v.2, p.3-20, 2016.

ZHAO, S.; SACHS, P.C.; WANG, X. et al. Mesenchymal stem cells in mammary adipose tissue stimulate progression of cancer breast resembling the basal-type. Cancer Biol. Ther., v.13, p.782-792, 2012.

ZHU, Y., LIU, T., SONG, K., FAN, X., MA, X., CUI, Z. Adipose-derived stem cell: a better stem cell than BMSC. Cell Biochem. Funct., v.26, p.664-675, 2008.

ZOMER, H.D.; VIDANE, A.S.; GONÇALVES, N.N.; AMBRÓSIO, C.E. Mesenchymal and induced pluripotent stem cells: general insights and clinical perspectives. Stem Cells Cloning, v.28, p.125-134, 2015.

ZUTTION, M.S.; WENCESLAU, C.V.; LEMOS, P.A.; TAKIMURA, C.; KERKIS, I. Células-Tronco de tecido adiposo e a importância da padronização de um modelo animal para experimentação pré-clínica. Rev. Bras. Cardiol. Invasive, v.21, p.281-287, 2013. 